\title{
Covid-19: \\ Selebgram Bicara, Selebgram Bertindak
}

\author{
Yuni Khaerunnisa Arta \\ Universitas Sawerigading \\ yunikhaerunnisaa@gmail.com
}

\begin{abstract}
The Covid-19 pandemic has greatly impacted on Indonesian life. Various efforts have been made by the government by issuing various policies, from implementing health protocols, Work From Home (WFH), large-scale social restrictions (PSBB), to the implementation of office activity restrictions (PPKM). To break the chain of transmission of Covid-19, even though the government is responsible for handling Covid-19, this is not only the duty of the government, but it is the joint duty of various elements of society, including the celebgram. This article deals with the role of celebgram in helping the government to break the chain of transmission of Covid-19.
\end{abstract}

This qualitative research was conducted in the city of Makassar as one of the cities in Indonesia that has experienced twice large-scale social restrictions (PSBB). Data was collected by combining in-depth interviews and observation. There were ten informants participated in this study, whose age are varied between 19 and 27 years, and four of them are university students. All of the informants work as celebgrams, but seven of them have multiple professions: four of them are celebgrams and freelancers, two of them are celebgrams and entrepreneurs; and one of them has triple professions, as a celebgram, model, as well as freelancer.

The study indicated that influencers such as celebgrams have a great opportunity to influence their followers because celebgrams are considered role models or people whose attitudes and behavior are imitated by their followers. To educate people in relation to Covid-19, celebgrams equip themselves with good and correct knowledge about Covid-19 which obtained from various sources, ranging from the internet, social media, television and other trusted sources of information. In doing so, celebgram have different metods, such as providing education through social media or going directly to the community. Education through social media is carried out in the form of live Instagram, creating educational videos regarding the importance of health protocols, and uploading them on their respective social media accounts. In addition, the celebgram also made efforts to prevent the transmission of the Covid-19 virus by going directly to the field which was carried out in the form of spraying disinfectants and distributing health protocol packages, such as hand sanitizers, masks and educational posters. They did this not as a public paid endorser, but as a form of moral responsibility to help the government in overcoming Covid-19. It is argued in this article that celebgram plays an important role in helping the government to break the chain of transmission of Covid-19.

Keywords: Covid-19, pandemic, celebgram, influencer, role, dan education. 
Jurnal Emik, Volume 4 Nomor 2, Desember 2021

\section{Pendahuluan}

Tahun 2020, dunia sedang dilanda wabah pendemi virus corona SARS-coV-2 (Covid-19). Covi-19 merupakan sekumpulan virus yang berasal dari subfamili Orthocronavirinae dalam keluarga Coronaviridae dan Ordo Nidovirales (Wahidah dkk. 2020). Virus ini dapat menjangkit hewan dan juga manusia, gejalanya mirip dengan penyakit MERS dan SARS, menyebabkan demam tinggi, batuk kering, cepat lelah dan rasa nyeri, sampai pada kematian. Virus ini pertama kali muncul di Negara China tepatnya di Kota Wuhan di akhir tahun 2019, lalu menyebar ke seluruh dunia sampai saat ini. Virus corona pertama kali ditemukan di Indonesia pada tanggal 02 Maret 2020 yang diumumkan pemerintah pusat oleh presiden, yaitu 2 WNI berasal dari Kota Depok yang diketahui memiliki riwayat kontak langsung dengan warga negara Jepang yang lebih dulu terinfeksi virus corona. ${ }^{1}$

Sampai saat ini Indonesia masih terus berjuang dalam menangani Covid-19 dimana jumlah masyarakat yang terinfeksi semakin hari semakin meningkat. Menurut data yang dilansir melalui web resmi Dinas Kesehatan Kota Makassar bahwa pada tanggal 19 Juli 2021 tercatat jumlah tambahan pasien Covid-19 baru mencapai 34.257 kasus, kenaikan kasus positif tersebut menjadikan angka terkonfirmasi secara akumulasi mencapai 2.911.733 orang, Satgas melaporkan penambahan kasus sembuh harian yakni 32.217 kasus, jumlah pasien yang meninggal karena Covid-19 mencapai 1.338 kasus sehingga totalnya menjadi 74.920 kasus. $^{2}$ Berdasarkan data tersebut, pemerintah terus berupaya untuk mencegah penyebaran virus corona yang melanda Indonesia, aturan serta kebijakan-kebijakan dikeluarkan untuk menekan lajunya penyebaran covid-19. Presiden

\footnotetext{
${ }^{1}$ https://indonesia.go.id/narasi/indonesia-dalamangka/ekonomi/kasus-covid-19-pertama-masyarakatjangan-panik, diakses tanggal 17 November 2020.
}

menetapkan peraturan tentang Pembatasan Sosial Berskala Besar melalui Peraturan Pemerintah (PP) Nomor 21 Tahun 2020 dan mentandatangani Keputusan Presiden Nomor 7 Tahun 2020 tentang Pembentukan Gugus Tugas Percepatan Penanganan Covid-19 (Gitiyarko 2020). Langkah ini diambil untuk memutus rantai penyebaran Covid-19 dengan perhatian khusus pada kesehatan masyarakat. Adapun kebijakankebijakan yang dikeluarkan oleh pemerintah yakni bekerja dari rumah (work form home), sekolah diliburkan, larangan beribadah di rumah ibadah, larangan mudik dan rumah makan atau tempat yang dapat memicu perkumpulan orangorang juga ditutup. Semua itu direalisasikan untuk membatasi segala aktivitas masyarakat yang dapat menyebabkan virus Covid-19 menyebar secara masif pada suatu tempat.

Berbagai upaya pemerintah tersebut dilakukan baik secara langsung maupun secara online, termasuk melalui media-media sosial (baca, misalnya, Suardi dan Yusuf 2021; Indika dan Jovita 2017). Berbagai studi menunjukkan signifikannya media sosial sebagai media promosi/pemasaran produk. Oleh karenanya Balakrishnan, dkk. (2014) merekomendasikan kepada pemasar untuk mengaplikasikan media sosial dalam mempromosikan produk karena media sosial merupakan media pemasaran yang penting dalam menjangkau segmen pasar, terutama usia muda dengan cara lebih cepat dan efisien.

Kehadiran media media sosial, seperti Instagram, juga memunculnya selebriti Instagram (selebgram) yang dapat menjadi agen dalam pemasaran produk dari toko online (endorsement). Fenomena endorsement ini muncul karena adanya timbal balik yang sesuai antara pengguna jasa endorsement dan

\footnotetext{
${ }^{2}$ https://infocorona.makassar.go.id/, diakses tanggal 23 November 2021.
} 
endorser. Selebgram menjadi opinion leader yang dapat memengaruhi para followers yang mengikutinya (follow). Ini karena, menurut Wati (2019:723), selebgram cenderung memiliki kedekatan dengan para pengikutnya, mereka dapat berinteraksi langsung dengan saling membalas komentar melalui fitur yang tersedia di Instagram. Meskipun itu kedekatan sebatas dunia maya, sebagaimana diargumentasikan oleh Sakinah (2018), bahwa selebgram adalah selebriti di dunia maya, bukan selebriti dunia nyata. Artinya, jika antara selebgram dan followers memiliki hubungan emosional antara satu dengan yang lain, hubungan itu hanya sebatas dunia maya. Sejumlah studi mengindikasikan signifikannya peran selebgram endorser sebagai sebagai media promosi produk (baca, misalnya, Maulana dkk. 2020; Nasih dkk. 2020).

Dalam memerangi pandemi Covid-19, ini tidak saja menjadi tanggungjawab pemerintah, tapi juga menjadi tanggungjawab semua elemen masyarakat, termasuk selebgram. Seseorang dikategorikan sebagai selebgram karena mereka memiliki banyak pengikut (followers) (Sakinah 2018:53; Rachmat dkk. 2016:2864). Oleh karena mereka memiliki banyak pengikut (followers), maka mereka akan sangat potensil untuk menjadi penyebar informasi melalui akun Instagram mereka (Sakinah 2018; Anjani dan Irwansyah 2020; Ramadhan dkk. 2020). Menurut Sakinah (2018), jumlah followers merupakan kriteria utama seseorang disebut selebgram, yang jumlahnya dapat mencapai ribuan bahkan jutaan followers.

Followers dari selebgram adalah penggemar dari seorang selebgram. Dengan demikian, semakin banyak jumlah followers, maka ini identik dengan semakin banyak penggemar. Dalam kaitan dengan ini, Anjani dan Irwansyah (2020:210-211) mengemukakan bahwa influencer dapat dikategorikan atas tiga berdasarkan jumlah pengikut dan status sosialnya di media sosial, yaitu: mega influencer atau selebrity influencer, macro influencer atau opinion leader, dan micro inluencer. Followers mengidolakan selebgram karena unggahannya yang dianggap menarik dan dapat dijadikan referensi gaya hidup bagi followers-nya. Dengan adanya legitimasi oleh para followers-nya, maka selebgram dapat memengaruhi pemikiran dan perilaku masyarakat melalui postingan yang diunggah. Dengan kata lain, selebgram dapat sekaligus sebagai influencer. Mereka dapat menjadi penyebar informasi tentang Covid-19 melalui akun Instagram, dan memengaruhi followers-nya. Ini dapat dibuktikan dengan studi Alam (2020) tentang peran influencer dalam upaya pencegahan Covid-19. la mengungkapkan bagaimana influencer menggunakan pendekatan yang bersifat bujukan atau ajakan. Pada setiap konten yang diposting bernuansa edukasi tentang pencegahan Covid-19, konten tersebut tidak mengandung informasi yang kontroversial. Bagi masyarakat yang tidak bisa memiliki akses internet, para influencer terjun ke lapangan untuk berkomunikasi secara langsung dengan public figure, mulai dari tokoh masyarakat hingga kepala daerah, yang menjadi jembatan antara influencer dan masyarakat.

Dalam konteks endorsement, menurut Ramadhan dkk. (2020), ada hubungan timbal balik yang saling menguntungkan antara pengguna jasa endorsement dan endorser. Dalam kaitan dengan upaya penanggulangan Covid-19, sejumlah instansi menggunakan jasa selebgram untuk tujuan tersebut. Namun, ada juga selebgram yang melakukannya sebagai tanggungjawab moral untuk ikut serta membantu pemerintah dalam upaya penanggulangan Covid-19.

Studi-studi mengenai peran selebgram/influencer selama masa pandemi Covid-19 telah banyak dilakukan (Ahmad dkk. 
2021; Risa dkk. 2020; Alam 2020). Dari sisi ekonomi, studi Ahmad dkk. (2021) yang berfokus pada peran influencer dalam memromosikan jualan atau jasa tertentu melalui media sosial di masa pandemi Covid-19 menunjukkan adanya peningkatan pendapatan yang signifikan bagi para pelaku usaha. Ini karena social media influencer dapat memengaruhi followers-nya untuk membeli barang atau jasa yang dipromosikan. Temuan Ratnapertiwi dkk. (2020) mengindikasikan peran signifikan influencer dan konten digital dalam menaikkan omzet bisnis online mereka di masa pandemi Covid-19. Dari sisi fund raising, studi Risa dkk. (2020) menunjukkan bagaimana influencer berperan penting terhadap keputusan donasi followersnya pada masa pandemi Covid-19. Ada beberapa faktor yang dapat memengaruhi followers dalam berdonasi, yakni: tujuan berdonasi, kepedulian terhadap pandemi, dan kepercayaan terhadap komunikator. Dari sisi pencegahan penyebaran Covid-19, peran signifikan influencer juga ditunjukkan dalam studi Alam (2020) yang mengindikasikan pentingnya komunikasi persuasif bagi influencer untuk menyebarkan informasi dengan pesan positif dan edukatif kepada followers-nya. Kontribusi baru dari studi ini dititikberatkan pada peran selebgram dalam mencegah penyebaran Covid-19 yang dilakukan sebagai tanggungjawab moral mereka bukan karena mereka dibayar untuk melakukan itu.

Artikel ini membahas tentang peran selebgram di tengah pandemi Covid-19 dalam upaya pencegahan penyebaran virus Covid-19. Pembahasan dalam artikel ini dibagi menjadi dua bagian. Bagian pertama membahas tentang bagaimana pengetahuan selebgram mengenai Covid-19. Bagian kedua, mengekplorasi tentang aktivitas selebgram dalam upaya pencegahan penyebaran Covid-19.

\section{Metode Penelitian}

Penelitian yang berlangsung antara bulan September dan November 2021 ini dilakukan di media sosial Instagram terhadap selebgram yang dalam akun pribadi mereka menunjukkan bahwa mereka melakukan edukasi tentang pencegahan penyebaran Covid-19.

Menurut Sakinah (2018), seseorang disebut selebgram jika memiliki ribuan hingga jutaan followers. Dalam konteks penelitian ini, pemilihan informan didasarkan pada jumlah followers dan kemenarikan konten yang diunggahnya, yakni yang memiliki lebih dari 5.000 followers dengan unggahan berkonten menarik. Mereka berjumlah sembilan orang yang berusia antara 19 dan 27 tahun, tiga orang berstatus mahasiswa. Semua informan berprofesi sebagai selebgram. Meskipun demikian, tujuh di antaranya berprofesi ganda, yakni empat orang berprofesi sebagai selebgram dan freelancer, dua orang berprofesi sebagai selebgram dan wirastawati; serta seorang sebagai selebgram, model, dan freleelancer.

\begin{tabular}{|c|l|c|c|c|c|l|}
\hline \multicolumn{7}{|c|}{ Tabel 1. Informan Penelitian } \\
\hline No. & Nama & $\begin{array}{c}\text { Umur } \\
\text { (Tahun) }\end{array}$ & \# Follower & Status & Pekerjaan & $\begin{array}{c}\text { Username } \\
\text { Instagram }\end{array}$ \\
\hline 1. & Fathur & 19 & $18,2 \mathrm{k}$ & Mahasiswa & Selebgram & @faturnehri \\
\hline 2. & Aura & 21 & $12,5 \mathrm{k}$ & Mahasiswi & Selebgram & @nurulauraa \\
\hline 3. & Lani & 25 & 6.801 & Mahasiswi & Model, Freelancer, Selebgram & @atnaprilyani \\
\hline 4. & Mitha & 19 & $15,7 \mathrm{k}$ & - & Freelancer, Selebgram & @heymiths \\
\hline
\end{tabular}


Covid-19: Selebgram Bicara, Selebgram Bertindak

\begin{tabular}{|l|l|l|l|l|c|l|}
\hline 5. & Ufy & 24 & $11,2 \mathrm{k}$ & - & Freelancer, Selebgram & @ufysastriana \\
\hline 6. & Endang & 27 & $15,9 \mathrm{k}$ & - & Freelancer, Selebgram & @endangsas \\
\hline 7. & Karmila & 23 & 9.017 & - & Wiraswastawati, Selebgram & @karmilawd \\
\hline 8. & Putri & 27 & 7.244 & - & Wiraswastawati, Selebgram & @putemuis \\
\hline 9. & Galuh & 24 & $16,9 \mathrm{k}$ & - & Freelancer, Selebgram & @gaaluhra \\
\hline
\end{tabular}

Teknik pengumpulan data yang digunakan pada penelitian ini adalah observasi dan wawancara mendalam. Observasi dilakukan selama penelitian berlangsung dengan mengamati konten yang diunggah oleh selebgram terkait pencegahan Covid-19 melalui media sosial pribadi dan mengamati respon followers mereka dengan melihat isi kolom komentar konten yang diunggah oleh selebgram terkait pencegahan Covid-19. Wawancara mendalam dilakukan untuk menggali informasi tentang peran selebgram dalam upaya pencegahan penyebaran virus Covid-19. Wawancara dilakukan secara chatting di Whatsapp dan Instagram. Topik-topik wawancara mencakup pengetahuan selebgram mengenai Covid-19, bagaimana selebgram beraktivitas selama pandemi Covid-19, dan aktivitas selebgram dalam upaya pencegahan penyebaran virus Covid-19.

Analisis data dilakukan dengan mengumpulkan data berupa hasil wawancara yang telah ditranskripsikan dan hasil dari observasi. Kemudian dilanjutkan dengan mengklasifikasikan data yang diperoleh sesuai dengan tema-tema temuan penelitian, seperti pengetahuan selebgram terkait Covid-19 dan peran selebgram dalam upaya pencegahan penyebaran virus Covid-19.

Dalam penelitian ini, perizinan dilakukan secara non-formal, yaitu meminta izin dengan cara menghubungi informan melalui aplikasi Whatsapp dan Instagram dengan terlebih dahulu memperkenalkan diri, maksud dan tujuan menghubungi informan, dan pertanyaan- pertanyaan yang berkaitan dengan topik penelitian. Proses perekrutan dimulai dengan melihat jumlah followers-nya (5.000 ke atas). Kemudian mereka dihubungi melalui Whatsapp atau Instagram untuk meminta kesediaan mereka berpartisipasi dalam penelitian ini. Jika informan menyetujui, mereka diminta izinnya untuk melakukan wawancara. Dua orang diwawancarai secara tatap muka dengan mematuhi protokol kesehatan dan delapan lainnya diwawancarai secara online dalam bentuk chatting melalui Whatsapp, videocall melalui Whatsapp, atau chatting melalui Instagram. Semua informan bersedia nama dan akun Instagram aslinya dicantumkan dalam artikel ini.

\section{Covid-19: Apa Kata Selebgram?}

Covid-19 berdampak ke berbagai aspek kehidupan yang membuat interaksi dan kegiatan masyarakat terhambat. Oleh karenanya, Presiden Joko Widodo mengimbau pengurangan aktivitas yang melibatkan banyak orang melalui arahannya untuk "Work From Home, Learn From Home, dan Pray From Home". Imbauan Presiden tersebut kemudian ditindaklanjuti dengan kebijakan di berbagai lini. Di Sulawesi Selatan, Gubernur mengeluarkan Surat Edaran (SE) Gubernur No. 800/3456/B.Organisasi tertanggal 4 Juni 2020 tentang Perpanjangan Penyesuaian Sistem Kerja Aparatur Negara. Isi dari Surat Edaran tersebut yakni, ASN yang berusia 50 tahun kebawah wajib melaksanakan tugas kedinasannya dari kantor; ASN yang berusia di atas 50 tahun dan tidak mengalami sakit 
melaksanakan tugas dari rumah/tempat tinggal dan dari kantor dengan persentase $50 \%$; ASN yang memiliki riwayat penyakit serius wajib menunjukkan surat keterangan sakit dan melaksanakan tugas kedinasannya dari rumah; ASN yang melaksanakan Work From Home yang sebelumnya hingga tanggal 19 Juni 2020 diperpanjang hingga tanggal 3 Juli 2020; dan Bupati/Wali Kota bertanggung jawab dalam melakukan pengawasan pelaksanaan ketentuan surat edaran tersebut.

Bagi selebgram yang memiliki kepedulian tentang ini, maka mereka sangat berpotensi menyebarkan informasi tentang Covid-19 kepada pengikutnya (followers) melalui akun Instagram. Ini karena selebgram memiliki banyak followers dan followers biasanya mengikuti apa yang dikatakan dan dilakukan oleh selebgram yang diikutinya. Pada kenyataannya banyak selebgram yang telah melakukannya. Kehadiran selebgram untuk mengedukasi merupakan salah satu cara yang efektif dalam upaya penyebaran informasi tentang Covid-19, mulai dari pengetahuan tentang Covid-19 itu sendiri, penyebarannya, pencegahan hingga penanganannya. Selebgram dianggap sebagai influencer yang dapat memberikan pengaruh besar dalam mengedukasi masyarakat tentang Covid-19.

Ada selebgram yang berpendapat tentang kemampuan berkomunikasi dan pengetahuan tentang apa yang akan disampaikan kepada orang yang ditargetkannya. Karmila (23 tahun), misalnya, mengemukakan bahwa seorang selebgram harus memiliki kemampuan dalam menyampaikan informasi kepada followersnya dan pengetahuan terkait apa yang ingin disampaikan. Misalnya, di tengah pandemi Covid-19, selebgram dapat menjadi influencer yang mengedukasi masyarakat tentang penerapan protokol kesehatan, resiko jika memiliki penyakit penyerta, bagaimana menjaga kesehatan agar tidak terinfeksi Covid19 , dan apa yang harus dilakukan jika terinfeksi Covid-19.

Sebagai selebgram, mereka juga terus memantau perkembangan Covid-19 agar informasi yang diberikan kepada masyarakat akurat dan tidak dikalahkan oleh berita hoaks. Lani (25 tahun), misalnya, mengungkapkan bahwa kesalahan mendapatkan informasi mengenai Covid-19 dapat berakibat fatal karena dapat membuat masyarakat yang menerima berita hoaks menjadi panik dan ketakutan. Oleh karena itu, Lani terus memantau perkembangan Covid-19 melalui website akun resmi milik Gugus Tugas Nasional dan WHO. Hal serupa juga dilakukan oleh Fathur (19 tahun) yang selalu meng-update informasi melalui internet, media sosial dan televisi yang menjadi modal baginya untuk menyebarkannya melalui akun Instagramnya.

Dalam kaitan dengan Covid-19 dan kematian, Aura (20 tahun) menjelaskan bahwa Covid-19 merupakan suatu virus yang memengaruhi sistem pernapasan dan bagi mereka yang memiliki riwayat penyakit penyerta, seperti diabetes, hipertensi, dan penyakit jantung, maka mereka akan beresiko mengalami komplikasi serius akibat terinfeksi Covid-19, bahkan dapat menyebabkan kematian. Artinya, bukan Covid-19 sebagai penyebab kematian. Tapi penyakit penyerta memperparah kondisi orang yang terinfeksi Covid-19. Namun, banyak informasi yang beredar bahwa Covid-19 adalah penyebab kematian. Hal ini yang diluruskan oleh Aura agar masyarakat memahaminya. Putri (27 Tahun) yang menganggap Covid-19 telah ditetapkan menjadi pandemi global yang keberadaannya akan terus ada dan kelak Covid-19 akan menjadi penyakit yang tidak lagi ditakuti karena kemungkinan besar akan sama posisinya seperti virus 
influenza. Pada akhirnya orang akan terbiasa hidup berdampingan dengan Covid-19.

Lalu faktor apa yang membuat orang berpotensi terinfeksi Covid-19. Ufy (24 tahun) menjelaskan bahwa jika seseorang mengalami penurunan imun, maka ia akan sangat mudah dimasuki virus, termasuk Covid-19. Banyak orang yang tidak memahami ini. Oleh karenanya, masyarakat perlu diedukasi dan selebgram adalah orang yang dapat berperan untuk membantu pemerintah dalam penyebaran informasi. Untuk itu, menurutnya, seorang selebgram harus memiliki pengetahuan tentang Covid-19, baik itu penyebab, cara mengatasi jika terinfeksi Covid-19, bagaimana mencegahnya, dll. sebagai modal awal dalam upaya membantu pemerintah untuk menyebarkan informasi yang benar ke masyarakat karena banyak hoaks yang beredar dan masyarakat tidak mengetahui perbedaan antara informasi yang benar dan informasi yang hoaks, dan cenderung mudah percaya pada berita-berita tersebut karena kontennya yang sangat provokatif.

Ada pula yang mengemukakan pendapatnya yang lebih spesifik dalam kaitan dengan pengetahuan dan kepatuhan masyarakat terhadap protokol kesehatan. Fatur (19 tahun), misalnya, mengemukakan bahwa masyarakat harus diedukasi tentang Covid-19 agar mereka mengetahui pentingnya mematuhi protokol kesehatan dalam upaya pencegahan penyebaran Covid-19. Jika tidak, mereka akan dengan mudah termakan oleh informasi hoaks yang beredar tak terkendali. Pendapat lain dikemukakan oleh Galuh (24 tahun) yang menganggap bahwa Covid-19 tidak hanya mematikan banyak jiwa, karena di sisi lain Covid-19 memberikan banyak kesempatan dan ruang untuk beradaptasi membentuk gaya hidup baru serta memiliki ruang untuk meningkatkan kualitas diri.

Jika merujuk pada berbagai pendapat

yang dikemukakan di atas, maka ini menunjukkan bahwa selebgram tidak saja membekali dirinya dengan pengetahuan tentang Covid-19 untuk disebarkan, tapi juga menyadari tentang banyaknya hoaks yang beredar di masyarakat yang terkait dengan Covid-19. Kepedulian terkait pandemi Covid-19 membuat mereka terpanggil untuk melakukan edukasi terhadap masyarakat agar mereka tidak menjadi bulan-bulanan penyebar hoaks terkait.

\section{Edukasi Covid-19 Ala Selebgram}

Selebgram termasuk influencer yang mempunyai tugas untuk memberikan review dan memengaruhi followersnya melalui konten menarik yang mereka posting. Selebgram memiliki kekuatan yang besar untuk memengaruhi orang lain. Dalam upaya memutus mata rantai penyebaran Covid-19, ini tidak saja menjadi tanggung jawab pemerintah semata, tetapi diperlukan peran serta masyarakat, termasuk selebgram.

Berbagai upaya telah dilakukan oleh pemerintah salah satunya dengan menerapkan protokol kesehatan 3M, yakni memakai masker, mencuci tangan, dan menjaga jarak. Penerapan $3 \mathrm{M}$ banyak terkait dengan peran individu dalam mengurangi penyebaran virus Covid-19. Oleh karena jumlah kasus Covid-19 semakin meningkat dari 44.721 ke 49.162 perharinya pada tanggal 19 Juli 2021, maka dari itu pemerintah meningkatkan protokol kesehatan dari 3M menjadi 5M (memakai masker, mencuci tangan, menjaga jarak, juga menghindari kerumunan dan mengurangi mobilitas). Ini berarti ada penambahan dua aspek protokol karena terjadinya peningkatan kasus Covid-19 yang dipicu oleh aktivitas berkumpul dan tingginya mobilitas masyarakat. Oleh karenanya, pemerintah menghimbau kepada masyarakat untuk menerapkan protokol kesehatan Covid-19 secara utuh dengan konsep 5M. 
Upaya selebgram dalam mengedukasi masyarakat merupakan bentuk kesadaran diri dan kepedulian mereka terhadap pandemi Covid-19 yang melanda Indonesia. Mereka menggunakan cara yang bervariasi dalam mengedukasi masyarakat. Lani (25 tahun), misalnya, melakukan edukasi melalui fitur Instagram, yaitu live Instagram milik pribadinya dan mengundang beberapa narasumber, seperti Miss Earth Indonesia 2019, Satgas Covid-19
Unhas, dan Walhi Sulsel. Mereka secara bersama-sama membahas tentang Covid-19 (seperti protokol kesehatan, pencegahan, menjaga imun, beraktivitas di masa pandemi (seperti bercocok tanam), lingkungan (seperti sampah, hidup yang ramah lingkungan), dll. Even ini mendapatkan respon positif dari followersnya yang dapat dilihat pada antusiasme followers-nya dalam menanggapi topik-topik yang dibicarakan (lihat Gambar 1).

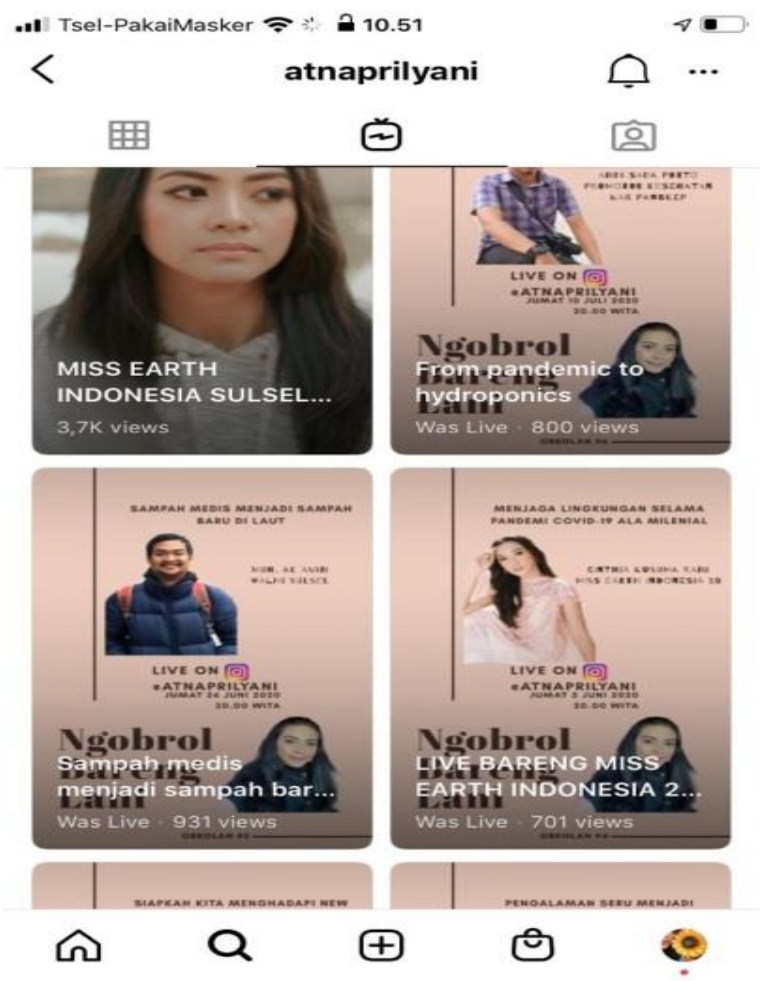

Gambar 1. Live Instagram @atnaprilyani

Aura (21 tahun) melakukan endorsement melalui akun Instagram pribadinya dengan mempromosikan produk atau barang dengan menerapkan protokol kesehatan sebagai edukasi lalu menyampaikannya ke followers via Instagram pribadinya (lihat Gambar 2). Selain itu, ia juga membantu dalam upaya penanggulangan Covid-19 melalui program KKN dengan tema
"Bersatu Melawan Covid". Melalui program KKN ini, Aura telah melakukan penyemprotan disinfektan untuk mensterilkan fasilitas umum dan UMKM yang ramai oleh pengunjung. la juga melakukan edukasi secara langsung tentang protokol kesehatan terkait tujuan dan pentingnya penerapan protokol kesehatan (lihat Gambar 3). 


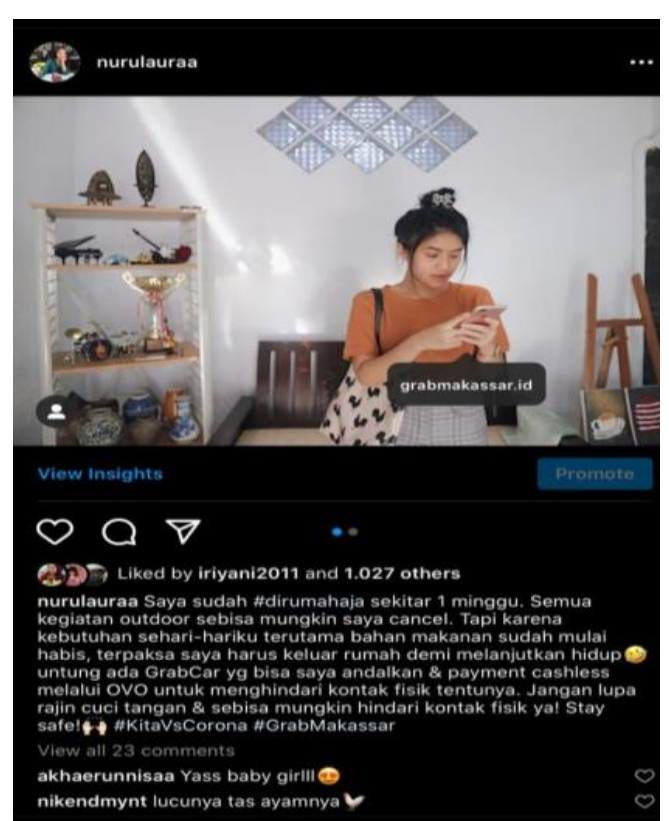

Gambar 2. Endorsement @nurulauraa

Upaya edukasi yang dilakukan oleh Aura sebagai seorang selebgram mendapatkan respon yang baik dari followers Instagramnya. Ini dibuktikan pada kolom komentar yang isinya berupa komentar positif, seperti apresiasi karena selain memromosikan produk atau barang Aura juga melakukan edukasi mengenai pentingnya penerapan protokol kesehatan. Bukti lainnya diperoleh dari respon followers-nya melalui impresson dan engangement dari postingannya di akun Instagramnya yang mencakup lebih dari 1000 akun pengguna.

Selain Aura, Fathur (19 tahun) juga telah melaksanakan program KKN dengan membuat poster kemudian menyebarkan poster terkait dengan pencegahan penyebaran Covid-19. Ini diikuti dengan pembagian alat-alat protokol kesehatan, seperti masker dan handsanitizer. Menurut Fathur, banyak hikmah yang ia peroleh dari program KKN kampusnya di tahun 2020, di antaranya ia dapat mengedukasi masyarakat agar lebih peka terhadap lingkungannya.

Aura (21 tahun), yang semakin resah dan cemas akan pandemi Covid-19, berinisiatif untuk membagikan bingkisan yang berisi handsanitizer,

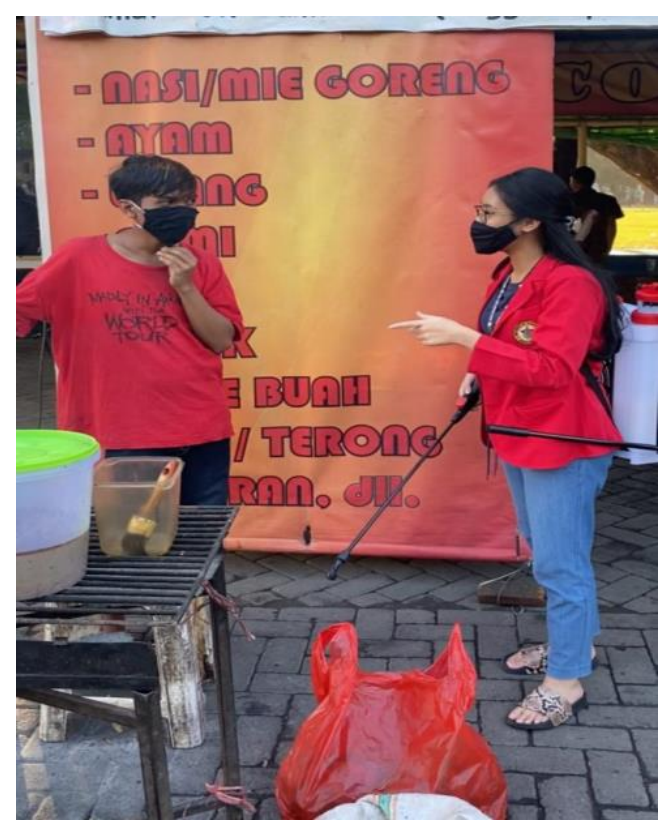

Gambar 3. Penyemprotan desinfektan dan edukasi langsung @nurulauraa

vitamin, dan poster edukasi dengan tujuan agar meningkatkan kesadaran masyarakat untuk memakai masker saat berada di luar rumah dan tetap melakukan physical distancing (jarak fisik). la juga mengedukasi masyarakat dalam hal penanganan Covid-19 dengan hal-hal kecil, seperti mencuci tangan, tata cara menggunakan masker dengan benar, dan informasi lainnya terkait Covid-19. Upaya ini dilakukannya karena kepeduliannya terhadap masyarakat, sehingga ia merasa terpanggil untuk mengedukasi mereka agar dapat meningkatkan kesadaran dan untuk mencegah penyebaran virus Covid-19.

Hal yang dilakukan oleh Ufy (24 tahun) dalam upaya mencegah penyebaran virus Covid19 adalah dengan membuat video terkait pentingnya menggunakan masker dan menjaga jarak dengan mengajak beberapa selebgram lain untuk terlibat dalam video tersebut. Lani (25 tahun) menyadari bahwa program edukasi melalui Instagram tidak cukup, maka ia mencari solusi lain dengan melakukan edukasi melalui Twitter dan menyampaikan secara langsung dengan tetap menerapkan protokol kesehatan. Sebagai orang kesehatan, Lani menjelaskan 
kepada masyarakat tentang pentingnya menjaga kesehatan tubuh dan mengajak orang berolah raga, meskipun ringan jogging, bersepeda, dll., tapi memberikan manfaat yang signifikan untuk menjaga imunitas di tengah pandemi Covid-19.

Ini serupa dengan yang dilakukan oleh Endang (27 tahun) yang juga menerapkan pola hidup sehat pada lingkungan sekitar tempat tinggalnya dan membuat video edukasi bersama anaknya dan diunggah melalui akun Youtube miliknya. Berbeda dengan Karmila (23 tahun) dan Mitha (19 tahun) yang tidak melakukan upaya pencegahan ke masyarakat, melainkan hanya di dalam lingkaran pertemanannya dengan selalu menerapkan protokol kesehatan. Karmila berpendapat dalam kaitan dengan bagaimana selebgram melakukan edukasi terkait Covid-19 kerpada masyarakat, bahwa program edukasi yang dilakukan oleh selebgram bersifat informatif. Oleh karenanya, ketika selebgram berperan dalam mengedukasi masyarakat, ini sangat diapresiasi oleh masyarakat.

Pembahasan di atas mengindikasikan bagaiman selebgram mengedukasi masyarakat dengan beragam cara, baik secara online melalui unggahan akun Instagram, status Twitter, live Instagram, video, hingga mengedukasi secara langsung dalam bentuk kegiatan edukasi yang terintegrasi dengan program KKN, penyemprotan desinfektan, dan membagi paket pencegahan Covid-19, dengan tetap mematuhi protokol kesehatan. Hal ini mendapatkan respon positif dari para followers-nya, maupun dari masyarakat ketika kegiatan terkait dilakukan secara langsung.

\section{Kesimpulan dan Rekomendasi}

Pandemi Covid-19 sudah sangat meresahkan masyarakat Indonesia karena meningkatnya angka pasien positif Covid-19. Berbagai upaya telah dilakukan oleh pemerintah dengan mengeluarkan berbagai kebijakan seperti Work
From Home, 3M yang kemudian meningkat menjadi 5M, bahkan pembatasan sosial berskala besar (PSBB), hingga pemberlakuan pembatasan kegiatan perkantoran (PPKM). Meskipun pemerintah bertanggungjawab dalam penanganan Covid-19, ini tidak semata menjadi tugas pemerintah, tapi menjadi tugas bersama berbagai elemen masyarakat, termasuk selebgram.

Influencer seperti selebgram memiliki peluang yang besar dalam memengaruhi followersnya karena selebgram dianggap sebagai panutan atau orang yang dicontohi sikap dan perilakunya oleh para followers-nya. Untuk mengedukasi masyarakat dalam kaitan dengan Covid-19, mereka membekali diri mereka dengan pengetahuan tentang Covid-19 yang diperoleh melalui berbagai sumber, mulai dari internet, media sosial, televisi dan sumber-sumber informasi lainnya.

Selebgram mempunyai cara yang berbeda-beda dalam upaya pencegahan penyebaran Covid-19. Edukasi melalui media sosial dilakukan dalam bentuk live Instagram, membuat video terkait pentingnya menerapkan protokol kesehatan di sela-sela melakukan endorsement, dan membuat video edukasi mengenai Covid-19 dan diunggah di akun media sosial masing-masing. Selain itu, selebgram juga melakukan upaya pencegahan penyebaran virus Covid-19 dengan cara terjun langsung ke lapangan yang dilakukan dalam bentuk penyemprotan desinfektan dan membagikan paket protokol kesehatan, seperti handsanitizer, masker dan poster edukasi. Dengan konteks ini, bahwa selebgram mengedukasi masyarakat bukan karena dibayar sebagaimana jika ia dijadikan sebagai endorse, tapi ini merupakan tanggungjawab moral bagi yang bersangkutan untukmembantu pemerintah dalam memutus mata rantai penyebaran Covid-19. 
Covid-19: Selebgram Bicara, Selebgram Bertindak

Studi ini membuktikan bahwa public figure seperti selebgram memiliki kekuatan untuk memengaruhi followers-nya berperan signifikan dalam upaya pencegahan penyebaran Covid-19 karena sebagai selebgram mereka dapat memengaruhi mereka. Oleh karenanya, selebgram dapat menjadi influencer yang berpengaruh dalam berbagai kegiatan edukasi tidak hanya di media sosial, tapi juga di dunia nyata. Jika studi ini terfokus pada peran selebgram di media sosial Instagram untuk mengedukasi masyarakat tentang Covid-19, maka studi lanjutan diharapkan dapat mengkaji tentang peran selebgram di dunia nyata untuk tujuan serupa dengan contoh kasus yang lebih banyak dan bervariasi agar dapat memeroleh gambaran yang lebih kompleks.

\section{Daftar Pustaka}

Ahmad, R.H.F.; Avicenna, R.; Sa'adah, R. 2020. Pemulihan Perekonomian Pada Masa Pandemi Covid-19 Berbasis Social Media Influencer di Era Ekonomi Digital, https://www.scribd.com/document/504 070853/Tinjauan-Literatur-Cenn-Fix, diakses tanggal 20 Mei 2020.

Alam, S. 2020. "Peran Influencer Sebagai Komunikasi Persuasif untuk Pencegahan Covid-19: the Role Of Influencer as Persuasive Communication For Covid- 19 Prevention", Jurnal Spektrum Komunikasi, Desember, 8(2):136-148, https://www.researchgate.net/publicati on/347738060 PERAN INFLUENCER SE BAGAI KOMUNIKASI PERSUASIF UNTU K PENCEGAHAN COVID-19, diakses tanggal 25 Oktober 2021.

Anjani, S. dan Irwansyah. 2020. "Peranan Influencer Dalam Mengkomunikasikan Pesan di Media Sosial Instagram", Polyglot, 16(2):203,
https://ojs.uph.edu/index.php/PJl/article /view/1929/pdf, diakses tanggal 1 Desember 2021.

Balakrishnan, B. K. P. D.; Dahnil, M. I.; dan Yi, W. J. 2014. "The Impact of Social Media Marketing Medium toward Purchase Intention and Brand Loyalty among Generation Y", Procedia - Social and Behavioral Sciences, Agustus, 148:177185,

https://www.sciencedirect.com/science Larticle/pii/S1877042814039366, diakses tanggal 10 Desember 2021.

Dasuki, I. and Wahid, U. 2020. "Penggunaan Instagram Sebagai Media Komunikasi Pemasaran Untuk Membangun Brand Awareness Saat Pandemi Covid-19", PARAHITA: Jurnal Pengabdian Kepada Masyarakat 1(2):47-54, https://www.semanticscholar.org/paper Penggunaan-Instagram-sebagai-MediaKomunikasi-untuk-DasukiWahid/f9c5d918b25f68d0f9c1323b8552 a382f834d416, diakses tanggal 15 November 2021.

Gitiyarko, V. 2020. "Upaya dan Kebijakan Pemerintah Indonesia Menangani Pandemi Covid-19", Kompaspedia, https://kompaspedia.kompas.id/baca/p aparan-topik/upaya-dan-kebijakanpemerintah-indonesia-menanganipandemi-covid-19, diakses tanggal 17 November 2020.

Indika D.R. dan Jovita, C. 2017. "Media Sosial Instagram Sebagai Sarana Promosi Untuk Meningkatkan Minat Beli Konsumen, Jurnal Bisnis Terapan, 01(1), 25-32, https://journal.ubaya.ac.id/index.php/JI BT/article/view/296/192, diakses tanggal 25 Oktober 2021. 
Maulana, I.; Manulang, J.M.; dan Salsabila, O. 2020. "Pengaruh Social Media Influencer Terhadap Perilaku Konsumtif di Era Ekonomi Digital", Majalah IImiah Bijak, 17(1): 28-34.

Nasih, M.; Susanto, O.M.; Fanshury, A.R.; dan Hermawan, S. 2020. "Influencer Dan Strategi Penjualan: Studi Netnografi Pada Pengguna Jasa Selebgram Sebagai Media Promosi", 5(2):135-144, https://journals.ums.ac.id/index.php/be nefit/article/view/11305/6320, diakses tanggal 25 Oktober 2020.

Prastyanti, Gita. 2017. Pengaruh Penggunaan Celebgram (Celebrity Endorser Instagram) Terhadap Minat Beli Konsumen Secara Online Pada Media Sosial Instagram: Studi Pada Mahasiswi Fakultas Ekonomi Dan Bisnis Universitas Lampung. Skripsi, Jurusan Manajemen FEB Universitas Lampung, Bandar Lampung, https://onesearch.id/Record/IOS2679.1 8587, diakses tanggal 25 Oktober 2021.

Rachmat, D. O.N.; Ariyanti, M.; dan Zuliestiana, D. A. 2016. "Pengaruh Celebrity Endorser di Media Sosial Instagram dalam Promosi Produk Hijab Terhadap Minat Beli Konsumen: Studi Kasus pada Akun Instagram @zahratuljannah dan @joyagh)", e-Proceeding of Management, Desember, 3(3): 28582865,

https://openlibrarypublications.telkomu niversity.ac.id/index.php/management/ article/view/3167, diakses tanggal 27 Oktober 2021.
Ramadhan, A.; Naswandi, C.N.; dan Herman, C.M. 2020. "Fenomena Endorsement di Instagram Story pada Kalangan Selebgram", KAREBA: Jurnal IImu Komunikasi, Juli-Desember, 9(2):316328),

https://journal.unhas.ac.id/index.php/k areba/article/view/8207, diakses tanggal 25 April 2021.

Ratnapertiwi, F.H.; Hafizd, A.; dan Febriani, P.S. 2021. "The Role of Influencers and Digital Content as a Marketing Strategy During the Covid-19 Pandemic", September, 1(3):241-246, https://ejournal.umm.ac.id/index.php/i amanika/article/view/17492, diakses tanggal 28 Oktober 2021.

Sakinah. 2018. "Selebgram: Meraih Popularitas Melalui Media Sosial". ETNOSIA: Jurnal Etnografi Indonesia, 3(1): 48-71,

https://journal.unhas.ac.id/index.php/e tnosia/article/view/4158, diakses tanggal 28 Agustus 2021.

Suardi, A. dan Yusuf, R. 2021. "Pengaruh Sosial Media Terhadap Keputusan pembeli Sepatu Kimber (@kimbershoes), Jurnal Ilmiah MEA (Manajemen, Ekonomi, dan Akuntansi)", $\quad$ 5(3):144-156, https://journal.stiemb.ac.id/index.php/ mea/article/view/1341, diakses tanggal 10 Desember 2021.

Wati, H. 2019. "Pengaruh Selebgram Sebagai Celebrity Endorsement terhadap Perilaku Konsumtif Mahasiwi", Sosietas, 9(2):722-727, https://ejournal.upi.edu/index.php/sosi etas/article/view/22822, diakses tanggal 10 Desember 2021. 